\title{
Lymphocyte counts and infection rates
}

\section{Long-term fingolimod treatment in primary progressive MS}

Edward J. Fox, MD, PhD, Fred D. Lublin, MD, Jerry S. Wolinsky, MD, Jeffrey A. Cohen, MD, Ian M. Williams, PhD, Xiangyi Meng, PhD, Marina Ziehn, PhD, Scott Kolodny, MD, and Bruce A.C. Cree, MD, PhD, MAS

Neurol Neuroimmunol Neuroinflamm 2019;6:e614. doi:10.1212/NXI.0000000000000614

\section{Abstract}

\section{Objective}

To evaluate lymphocyte counts and incidences of infections in patients with primary progressive MS (PPMS) receiving fingolimod $0.5 \mathrm{mg} / \mathrm{d}$ or placebo over 5 years during the INFORMS study, to assess infection rates with longer-term treatment.

\section{Methods}

INFORMS was a randomized, multicenter, double-blind, placebo-controlled, parallel-group, phase 3 study of the sphingosine 1-phosphate receptor modulator fingolimod in patients with PPMS. Lymphocyte counts and incidences of infections were compared in patients receiving fingolimod or placebo. Infection rates were assessed in patients receiving fingolimod according to nadir and mean absolute lymphocyte count (ALC).

\section{Results}

Overall, 336 patients received fingolimod $0.5 \mathrm{mg} / \mathrm{d}$ (total exposure: 908.1 patient-years), and 487 received placebo (1,423.5 patient-years). In patients receiving fingolimod, mean ALC decreased by approximately $70 \%$ in the 2 weeks following treatment initiation and remained stable throughout the study. The incidences of all infections in the fingolimod and placebo groups were similar (53.6 vs 51.9 per 100 patient-years). The most common infections in patients receiving fingolimod were urinary tract infections (5.7 per 100 patient-years), upper respiratory tract infections (4.2 per 100 patient-years), and influenza (3.2 per 100 patientyears); incidences were similar in the placebo group (5.9, 4.2, and 3.1 per 100 patient-years, respectively). There was no apparent association between nadir or mean ALC and incidence of infection-related adverse events.

\section{Conclusions}

In patients with PPMS, long-term treatment with fingolimod $0.5 \mathrm{mg} / \mathrm{d}$ for up to 5 years led to an expected decrease of approximately $70 \%$ in mean ALC and did not appear to correlate with increased risk of infection.

\section{Classification of evidence}

Because this is a secondary analysis, this study provides Class II evidence that long-term PPMS treatment with fingolimod decreased mean ALC by approximately $70 \%$, but did not significantly increase infection risk.

\author{
Correspondence \\ Dr. Fox \\ foxtexms@gmail.com
}

\section{MORE ONLINE}

$\rightarrow$ Class of Evidence

Criteria for rating therapeutic and diagnostic studies

NPub.org/coe 


\section{Glossary}

AE $=$ adverse event ALC $=$ absolute lymphocyte count EDSS = Expanded Disability Status Scale; IgG = immunoglobulin G; PPMS = primary progressive multiple sclerosis; RTI = respiratory tract infection; S1P = sphingosine 1-phosphate; VZV = varicella zoster virus.

Fingolimod is the first sphingosine-1-phosphate (S1P) receptor modulator approved for the treatment of patients with relapsing forms of MS. ${ }^{1-3} \mathrm{~S} 1 \mathrm{P}$ is a bioactive phospholipid that regulates a range of processes, including cell differentiation, cell migration, immunity, and inflammation. Its effects are mediated by the G-protein-coupled receptor subtypes $\mathrm{S}_{1} \mathrm{P}_{1-5}$, of which $\mathrm{S}_{1} \mathrm{P}_{1}, \mathrm{~S}_{1} \mathrm{P}_{3}$, and $\mathrm{S}_{1} \mathrm{P}_{4}$ play an important part in lymphocyte egression from lymph nodes. ${ }^{4,5}$

Fingolimod is a structural analog of sphingosine and, once phosphorylated, is a functional antagonist of receptor subtypes $\mathrm{S}_{1} \mathrm{P}_{1,3-5}$. The therapeutic effects of fingolimod are presumed to be mediated via $\mathrm{S}_{1} \mathrm{P}_{1}$ receptors on lymphocytes, where binding leads to receptor internalization and degradation, inhibiting lymphocyte migration from lymph nodes. This mechanism reduces levels of circulating lymphocytes in a dose-dependent manner (mean reduction of approximately $70 \%) .{ }^{6-8}$ However, specifically in patients with relapsing-remitting MS, reduced levels of circulating lymphocytes appear not to be a predictor of fingolimod efficacy. ${ }^{9}$

The redistribution of circulating lymphocytes might lead to an increased incidence of infections. Indeed, while the overall incidences of infection were similar with fingolimod, interferon $\beta$, or placebo in phase 3 trials, ${ }^{7,10,11}$ a small increase in the risk of certain infections (particularly herpes and respiratory tract infections [RTIs]) and rare incidences of serious opportunistic infections have been reported with fingolimod in the postmarketing setting. ${ }^{1-3,5,12,13}$ Here, safety data from INFORMS (a double-blind, randomized, multicenter, placebo-controlled, parallel-group study comparing the efficacy and safety of $0.5 \mathrm{mg}$ fingolimod, administered orally once daily vs placebo in patients with primary progressive MS [PPMS]) were assessed to determine whether the reduction of absolute lymphocyte count (ALC) associated with fingolimod treatment correlated with an increased incidence of infection.

\section{Methods}

Methods for the oral fingolimod in PPMS study (INFORMS; CFTY720D2306; ClinicalTrials.gov Identifier: NCT00731692) are detailed elsewhere ${ }^{14}$ and described briefly below. This substudy was designed to evaluate lymphocyte counts and incidences of infections and skin malignancies in patients with PPMS receiving fingolimod $0.5 \mathrm{mg} / \mathrm{d}$, including additional analyses of those who switched from the $1.25 \mathrm{mg} / \mathrm{d}$ dose to 0.5 $\mathrm{mg} / \mathrm{d}$, or placebo over 5 years during the INFORMS study.

\section{Standard protocol approvals and patient consent}

INFORMS was conducted in accordance with the International Conference on Harmonization Good Clinical Practice Guideline and the Declaration of Helsinki. ${ }^{15}$ Each institutional review board of the participating sites approved the protocol. All patients gave written informed consent to take part in the study.

\section{Study design}

This randomized, multicenter, double-blind, placebocontrolled, parallel-group, phase 3 study was conducted at 148 centers in 18 countries. Patients were enrolled from September 3, 2008 to August 30, 2011.

\section{Patients}

Inclusion and exclusion criteria for INFORMS were reported. ${ }^{14}$ In brief, patients enrolled in the trial were 25 to 65 years old and had a clinical diagnosis of PPMS according to the 2005 revised McDonald criteria (i.e., they had 1 year or more of disease progression and met 2 of the following criteria: brain lesion confirmed by MRI, spinal cord lesion confirmed by MRI, or evidence of elevated intrathecal synthesis of gamma-immunoglobulins in CSF). ${ }^{16}$ In the original study protocol, varicella zoster virus (VZV) immunoglobulin G ( $\operatorname{IgG}$ ) status was not part of the inclusion/exclusion criteria. A later protocol amendment was included to exclude participants negative for VZV IgG antibodies at screening; this is in line with the prescribing guidance in both the US and Europe. ${ }^{1,2}$ The final randomized set included one patient in the placebo group $(1 / 480[0.2 \%])$ and none in the fingolimod $(0 / 330)$ group testing negative for VZV IgG.

\section{Randomization}

Patients were randomly assigned (1:1) to receive either daily oral fingolimod or placebo. ${ }^{14}$ All randomized drug assignments remained masked to patients, investigators, people performing the assessments, and data analysts for the entire double-blind treatment period (at least 36 months and up to 5 years). Treatment codes were accessible only to members of the data and safety monitoring board, which was independent of the study sponsor and not otherwise involved in the study.

Patients were initially assigned to receive fingolimod $1.25 \mathrm{mg} /$ $\mathrm{d}$ or placebo (cohort 1). After the decision to select the 0.5 $\mathrm{mg} / \mathrm{d}$ dose of fingolimod for submission to regulatory authorities and to discontinue development of fingolimod 1.25 $\mathrm{mg} / \mathrm{d}$, the protocol was amended on November 19, 2009. At this point, allocation of patients to the $1.25 \mathrm{mg} / \mathrm{d}$ cohort was stopped, and those receiving that dose of fingolimod were 
switched in a masked manner to fingolimod $0.5 \mathrm{mg} / \mathrm{d}$; those assigned to placebo continued on placebo. Patients enrolled after the protocol amendment were randomly allocated to receive fingolimod $0.5 \mathrm{mg} / \mathrm{d}$ or placebo (cohort 2). During follow-up, treatment was interrupted in patients who had a confirmed ALC below $0.2 \times 10^{9} / \mathrm{L}$ at any visit (2 weeks, 1, 2, and 3 months after randomization, and every 3 months thereafter). In such patients, the ALC was subsequently monitored monthly, and fingolimod was reinitiated when the ALC reached $0.6 \times 10^{9} / \mathrm{L}$ or higher.

\section{Outcomes}

The primary analysis in this study was performed to evaluate lymphocyte counts and compare the incidences of all infections and skin malignancies in patients who exclusively received fingolimod $0.5 \mathrm{mg} / \mathrm{d}$ with those who received placebo for up to 5 years. Incidences of individual RTIs, herpes infections, and other types of infection in both groups were also assessed separately. In the fingolimod $0.5 \mathrm{mg} / \mathrm{d}$ group, results were stratified by patient nadir and mean ALC. A secondary analysis was performed to assess the incidences of infections in patients in cohort 1 who received fingolimod $1.25 \mathrm{mg} / \mathrm{d}$ and patients who switched from the $1.25 \mathrm{mg} / \mathrm{d}$ to fingolimod 0.5 $\mathrm{mg} / \mathrm{d}$. Additional analyses included evaluation of cumulative infectious event rates over time using Kaplan-Meier analyses, and logistic analyses to assess the potential effects of corticosteroid use, baseline Expanded Disability Status Scale (EDSS) score, and age on risk of infection, as well as discontinuation rates among patients receiving fingolimod.

\section{Statistical analyses}

Numbers and incidences of infection-related adverse events (AEs) in the fingolimod treatment groups (overall, and by nadir and mean ALC) and the placebo group are reported. Incidences of infections were calculated per 100 patient-years, based on a summation of the number of patients who experienced infection events and the total patient exposure occurring between the date of first dose of study drug or placebo, and up to 45 days after the last dose or up to February 28, 2017, whichever was the earlier. By including a period of up to 45 days after the final dose, the reported $\mathrm{AE}$ data should capture all treatment-related AEs. Overall, this allows for the long-term assessment of infection rates in patients with PPMS.

\section{Data availability}

Anonymized data not published within this article will be shared by request from any qualified investigator.

\section{Results}

In total, 970 patients were randomized to receive fingolimod $1.25 \mathrm{mg} / \mathrm{d}(\mathrm{n}=147)$ or placebo $(\mathrm{n}=133)$ in cohort 1 , and fingolimod $0.5 \mathrm{mg} / \mathrm{d}(\mathrm{n}=336)$ or placebo $(\mathrm{n}=354)$ in cohort 2 . Thus, 336 patients received fingolimod $0.5 \mathrm{mg} / \mathrm{d}$ (cohort 2 ), and 487 patients received placebo (cohorts 1 and 2) and were included in the primary analysis. Baseline characteristics of patients included in the primary analysis (i.e., patients who exclusively received fingolimod $0.5 \mathrm{mg} / \mathrm{d}$ or placebo) were similar (table 1 ).

Patients receiving fingolimod $0.5 \mathrm{mg} / \mathrm{d}$ were followed up for a median of 3.1 years (1,123.5 days; range 20-1,612 days; total exposure 908.1 patient-years), and those receiving placebo were followed up for a median of 3.2 years (1,166.0 days; range 1-1860 days; total exposure 1,423.5 patient-years). In patients who received fingolimod $0.5 \mathrm{mg} / \mathrm{d}$, mean ALC decreased by approximately $70 \%$ in the 2 weeks following treatment initiation and remained stable throughout the study (mean ALC 0.5 $\times 10^{9} / \mathrm{L}$; SD 0.3; figure $1 \mathrm{~A}$ ). The proportion of patients with ALC falling below the threshold for drug interruption $(<0.2 \times$ $10^{9} / \mathrm{L}$ ) did not increase with duration of fingolimod exposure. After 2 months of treatment, between $2.5 \%$ and $6.8 \%$ of patients had ALC below $0.2 \times 10^{9} / \mathrm{L}$ at any visit. This proportion remained stable throughout the study (figure 1B). Only one of the 336 patients who received fingolimod $0.5 \mathrm{mg}$ / $\mathrm{d}(0.3 \%)$ discontinued fingolimod for the duration of the trial because of reduced ALC. In the 3 months following fingolimod discontinuation, the mean ALC recovered to $1.4 \times 10^{9} / \mathrm{L}$ (SD 0.6 ), which is approximately $75 \%$ of the mean baseline value (figure e-1 links.lww.com/NXI/A144).

The frequencies of infections and infestations were similar for those receiving fingolimod $0.5 \mathrm{mg} / \mathrm{d}$ and placebo (figure 2). Most patients reported 2 or fewer infections: $73.8 \%$ of patients $(248 / 336)$ receiving fingolimod $0.5 \mathrm{mg} / \mathrm{d}$ and $71.0 \%$ of patients $(345 / 486)$ receiving placebo. The proportions of patients who did not experience any infections were almost identical in the fingolimod $0.5 \mathrm{mg} / \mathrm{d}$ and placebo groups (31.8\% [107/336] and 31.3\% [152/486], respectively). The proportions of patients reporting 10 or more infections were also similar for fingolimod $0.5 \mathrm{mg} / \mathrm{d}(1.8 \%[6 / 336])$ and placebo $(2.7 \%$ [13/486]). There was no trend in the number of infections when data for the fingolimod $0.5 \mathrm{mg} / \mathrm{d}$ group were stratified by nadir ALC.

Incidences of all infections, RTIs, and herpes infections are shown in figure 3. Overall, incidences for all infections and RTIs were similar in the fingolimod $0.5 \mathrm{mg} / \mathrm{d}$ and placebo groups (53.6 vs 51.9 infections per 100 patient-years and 16.4 vs 18.1 RTIs per 100 patient-years, respectively). Similarly, the incidence of herpes infections (including oral herpes, herpes simplex, herpes zoster, herpes zoster meningomyelitis, genital herpes, neurologic herpes, ophthalmic herpes simplex, and ophthalmic herpes zoster) was the same in both groups (2.5 herpes infections per 100 patient-years). No cases of serious opportunistic infections, such as progressive multifocal leukoencephalopathy, disseminated varicella, and cryptococcal infections, were reported in either group. No associations between nadir or mean ALCs and incidence of infections were observed (figure $3, \mathrm{~A}$ and $\mathrm{B}$, respectively).

The incidences of different infection types reported by at least $2 \%$ of patients in the fingolimod $0.5 \mathrm{mg} / \mathrm{d}$ and/or the placebo group during the follow-up period (from administration of the 
Table 1 Patient demographics and clinical characteristics at baseline

\begin{tabular}{|c|c|c|}
\hline & $\begin{array}{l}\text { Fingolimod } 0.5 \mathrm{mg} / \mathrm{d} \\
(\mathrm{n}=336)\end{array}$ & $\begin{array}{l}\text { Placebo } \\
(n=487)\end{array}$ \\
\hline \multicolumn{3}{|l|}{ Sex, n (\%) } \\
\hline Male & $173(51.5)$ & $252(51.7)$ \\
\hline Female & $163(48.5)$ & 235 (48.3) \\
\hline Age, y & $48.5(8.6)$ & $48.5(8.3)$ \\
\hline \multicolumn{3}{|l|}{ Age category, n (\%) } \\
\hline $25-30 y$ & $6(1.8)$ & $4(0.8)$ \\
\hline $31-40 y$ & 60 (17.9) & 90 (18.5) \\
\hline $41-50 y$ & $127(37.8)$ & 194 (39.8) \\
\hline $50 y$ & $143(42.6)$ & 199 (40.9) \\
\hline \multicolumn{3}{|l|}{ Race, n (\%) } \\
\hline Caucasian & $324(96.4)$ & 467 (95.9) \\
\hline Black & $7(2.1)$ & $6(1.2)$ \\
\hline Asian & $0(0.0)$ & $4(0.8)$ \\
\hline Other & $5(1.5)$ & $10(2.1)$ \\
\hline Weight, kg & $74.6(15.3)$ & $74.5(15.2)$ \\
\hline Height, cm & $171.2(9.2)$ & $170.5(9.5)$ \\
\hline BMI, kg/m² & $25.4(4.5)$ & $25.6(4.5)$ \\
\hline \multicolumn{3}{|l|}{ Duration of PPMS, y } \\
\hline Since diagnosis & $2.8(2.6)$ & $2.9(2.3)$ \\
\hline $\begin{array}{l}\text { Since first } \\
\text { symptoms }\end{array}$ & $5.8(2.5)$ & $5.9(2.4)$ \\
\hline \multicolumn{3}{|l|}{ Disability scores } \\
\hline EDSS & $4.7(1.0)$ & $4.7(1.0)$ \\
\hline 25FWT, s & $9.1(5.6)$ & $9.1(7.6)$ \\
\hline 9HPT, s & $28.4(11.5)$ & $28.8(16.5)$ \\
\hline Gd+ lesion volume, $\mathrm{mm}^{3}$ & $73.5(337.1)$ & $35.9(163.4)$ \\
\hline T2 lesion volume, $\mathrm{mm}^{3}$ & $9,442.7(10,179.7)$ & $\begin{array}{l}10,038.2 \\
(13,030.9)\end{array}$ \\
\hline $\begin{array}{l}\text { Normalized brain volume, } \\
\mathrm{cm}^{3}\end{array}$ & $1,490.9(86.5)$ & $1,491.7(84.9)$ \\
\hline
\end{tabular}

\begin{tabular}{lll}
\hline History of DMT use, $\mathbf{n}(\%)$ & & $372(76.4)$ \\
\hline Treatment-naïve & $272(81.0)$ & $66(13.6)$ \\
\hline Any interferon $\boldsymbol{\beta}$ & $36(10.7)$ & $33(6.8)$ \\
\hline Glatiramer acetate & $26(7.7)$ & $2(0.4)$ \\
\hline Natalizumab & $3(0.9)$ & $36(7.4)$
\end{tabular}

Abbreviations: 25FWT = 25-foot walk test; $9 \mathrm{HPT}=$ 9-hole peg test; $\mathrm{BMI}=$ body mass index; DMT = disease-modifying therapy; EDSS = Expanded Disability Status Scale; Gd+ = gadolinium-enhancing; PPMS = primary progressive MS.

Data are reported as mean (SD) unless otherwise stated. first dose of study drug or placebo to 45 days after the last dose or up to February 28, 2017, whichever was the earlier) are shown in table 2 . The most common infections in patients who received fingolimod $0.5 \mathrm{mg} / \mathrm{d}$ were urinary tract infections ( 5.7 per 100 patient-years), upper RTIs (4.2 per 100 patient-years), and influenza (3.2 per 100 patient-years). Incidences for these infections were similar in patients who received placebo (5.9, 4.2 , and 3.1 per 100 patient-years, respectively), as well as across nadir ALC subgroups of those receiving fingolimod $0.5 \mathrm{mg} / \mathrm{d}$. Incidences of other types of infections were similarly low in the fingolimod $0.5 \mathrm{mg} / \mathrm{d}$ and placebo groups.

A few patients who received fingolimod $0.5 \mathrm{mg} / \mathrm{d}$ had a low white blood cell count $\left(\leq 2 \times 10^{9} / \mathrm{L} ; \mathrm{n}=11\right)$, a low absolute neutrophil count $\left(\leq 1 \times 10^{9} / \mathrm{L} ; \mathrm{n}=2\right)$, or both a low white blood cell count and a low ALC $\left(\leq 2 \times 10^{9} / \mathrm{L}\right.$ and $<0.2 \times 10^{9} /$ $\mathrm{L} ; \mathrm{n}=4)$ at any visit. The incidences of any infections were higher in these subgroups (100.0, 220.0, and 178.2 per 100 patient-years, respectively; table e-1, links.lww.com/NXI/ A144) than in the overall population of patients who received fingolimod $0.5 \mathrm{mg} / \mathrm{d}$ (53.6 per 100 patient-years). Since these patient numbers were small $(n=17$, in all), these findings should be interpreted with caution.

In the 147 patients in cohort 1 who received fingolimod 1.25 $\mathrm{mg} / \mathrm{d}$, incidences of all infections $(87.8$ per 100 patientyears), RTIs (30.5 per 100 patient-years), and herpes infections (3.3 per 100 patient-years) were nominally higher than those observed in patients who received fingolimod $0.5 \mathrm{mg} /$ $\mathrm{d}$ or placebo (figure e-2, links.lww.com/NXI/A144). When the incidence data for patients who received fingolimod 1.25 $\mathrm{mg} / \mathrm{d}$ were stratified by mean or nadir ALC, no association was seen between incidences of infection and ALC subgroups. Overall, analysis of Kaplan-Meier plots of cumulative event rate data for time to first infection were similar among patients receiving fingolimod $0.5 \mathrm{mg} / \mathrm{d}$ or placebo (figure e-3, links. lww.com/NXI/A144).

In a logistic regression analysis of infection risk after adjustment for treatment and administration of systemic corticosteroids, no differences were observed between treatment groups, indicating that patients treated with fingolimod are not at elevated risk of infection. There was, however, a possible association between risk of infection and the use of systemic corticosteroids, independent of fingolimod treatment (odds ratio 1.76 [95\% CI: $1.22 ; 2.53$ ]; $p=0.0024$ ). Similarly, there were no treatment effects on risk of infection according to age and baseline EDSS score, although baseline EDSS score itself may be associated with increased risk of infection $(p=0.0126)$. This was not the case for age $(p=0.7003)$.

Analysis of infection rates among patients who switched from fingolimod 1.25 to $0.5 \mathrm{mg} / \mathrm{d}$ showed that there were no differences in the pattern of infections when stratified by nadir ALC (table e-2, links.lww.com/NXI/A144). The same observation was made when infection rates were stratified by mean ALC (table e-3, links.lww.com/NXI/A144). 


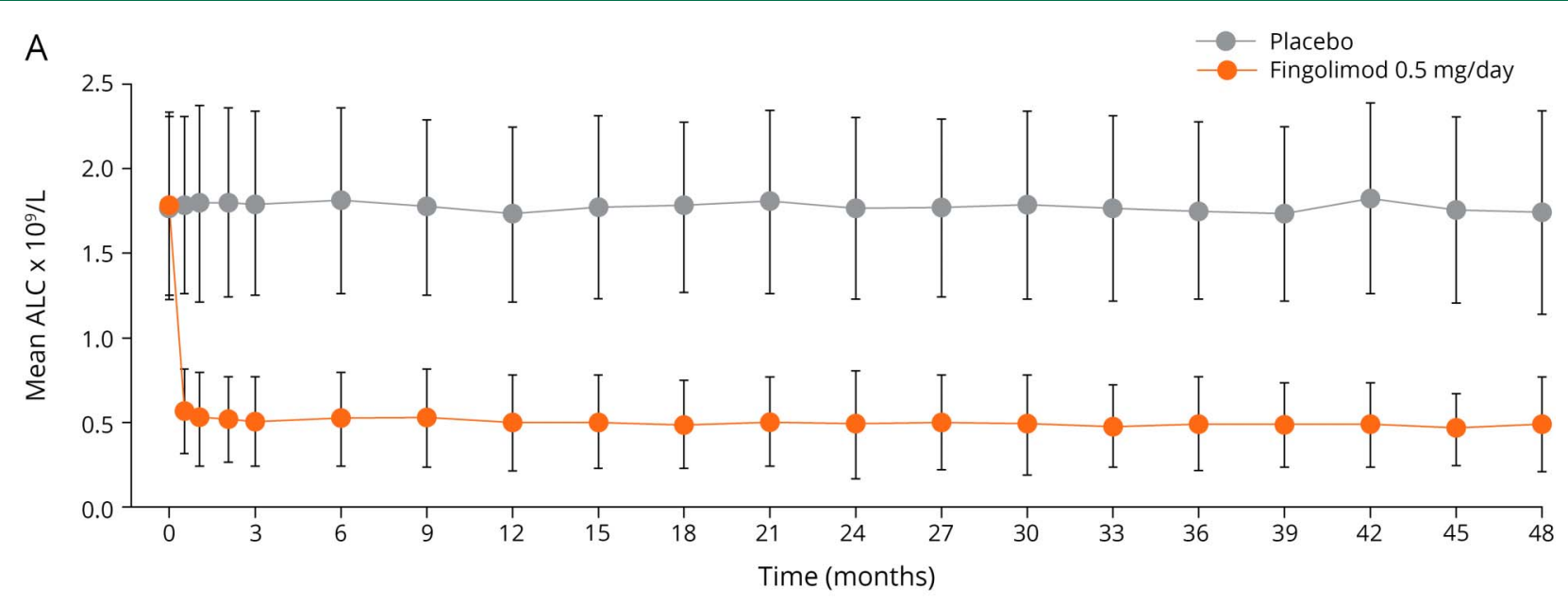

B

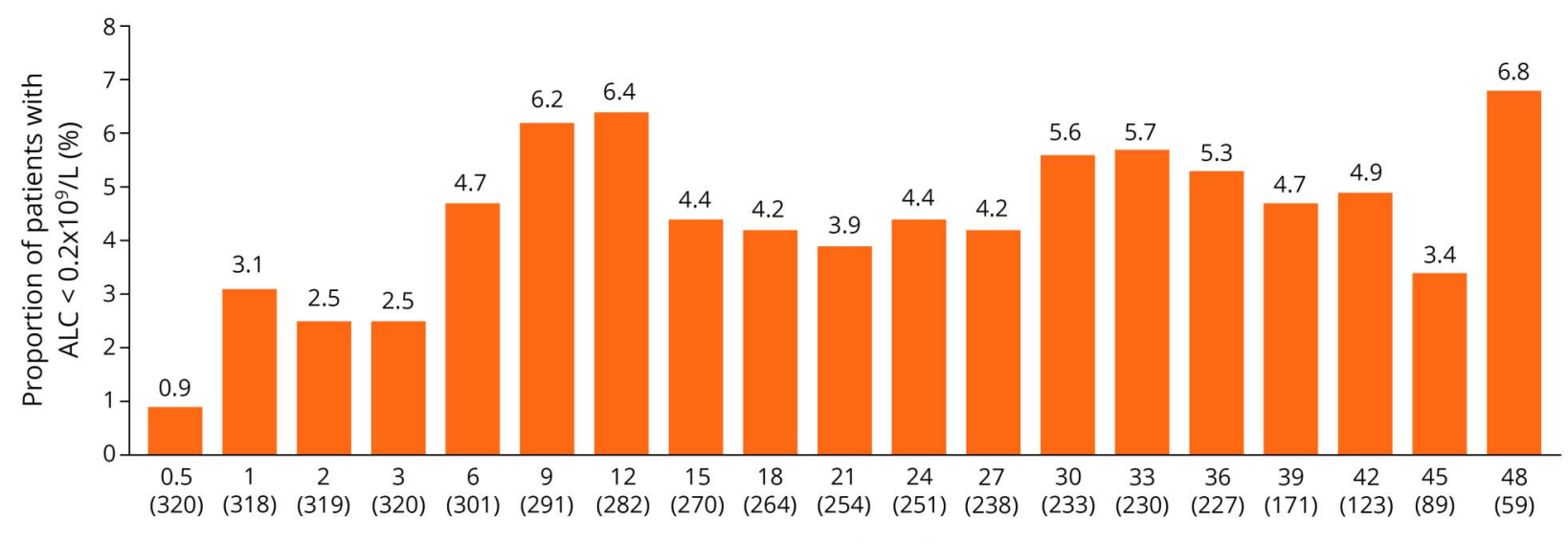

Month (number of patients)

(A) Mean ALC during follow-up in patients who received fingolimod $0.5 \mathrm{mg} / \mathrm{d}$ or placebo. (B) Proportion of patients with $\mathrm{ALC}<0.2 \times 10^{9} / \mathrm{L}$ in the fingolimod 0.5 $\mathrm{mg} / \mathrm{d}$ group. Error bars represent SD. ALC = absolute lymphocyte count.

Overall, rates of discontinuation owing to infections were low and similar between treatment groups: $5 / 336(1.5 \%)$ patients receiving fingolimod discontinued, and 6/487 (1.2\%) patients receiving placebo discontinued.

Rates of skin malignancies were similar across all stratifications by mean or nadir ALC (table e-4, links.lww.com/NXI/A144). Incidence stratified by mean ALC ranged between $0 \%$ and $6.3 \%$ for basal cell carcinoma, $0 \%$ and $1.1 \%$ for malignant melanoma, $0 \%$ and $4.5 \%$ for squamous cell carcinoma of the skin, and $0 \%$ and $6.7 \%$ for any skin cancer. Similar results were obtained when data were stratified by nadir ALC, and there was no association between incidence of skin malignancy and ALC count.

\section{Discussion}

Although the INFORMS study did not demonstrate efficacy in relation to its primary endpoint (time to 3-month confirmed worsening on a composite disability outcome measure), ${ }^{14}$ this long-term, placebo-controlled trial in patients with PPMS provides valuable insight into the safety profile of fingolimod and the effect of long-term exposure to the drug. Notably, this study also provided data for the incidence of infections in an MS population that may be at increased risk of infections owing to older age and disease severity compared with patients with relapsing forms of $\mathrm{MS} .^{17-19}$

At the fingolimod dose of $0.5 \mathrm{mg} / \mathrm{d}$, approved by the US Food and Drug Administration and the European Medicines Agency for the treatment of relapsing forms of $\mathrm{MS},{ }^{1,2}$ fingolimodrelated reductions in ALC were not associated with an increased incidence of all infections, upper RTIs, herpes infections, or influenza infections when compared with placebo treatment. The incidences of other types of infections were similarly low with fingolimod $0.5 \mathrm{mg} / \mathrm{d}$ and placebo. No serious opportunistic infections were observed during the study. Fingolimod-associated reductions in mean ALC remained stable for over 4 years of treatment, with no new safety signals 


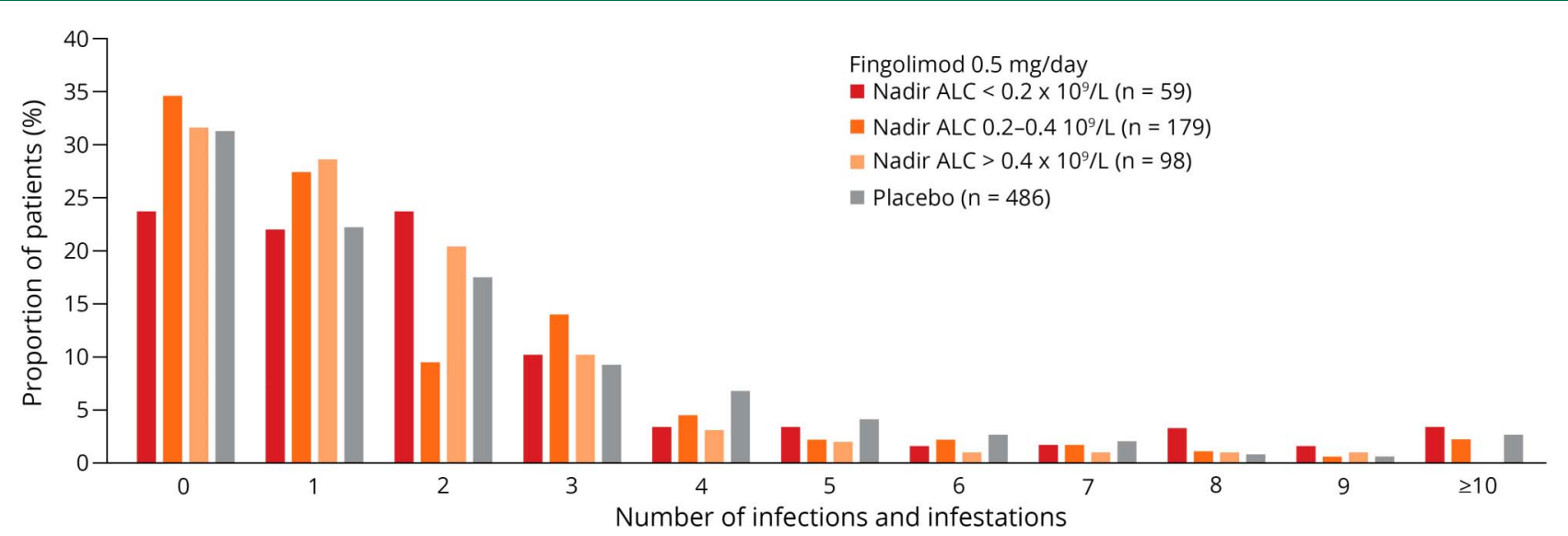

Proportions of patients experiencing from 0 to 10 or more infections and infestations in the groups receiving fingolimod $0.5 \mathrm{mg} / \mathrm{d}$ (stratified by nadir ALC) and placebo. $A L C=$ absolute lymphocyte count.

relating to reduced lymphocyte count. Recovery toward baseline ALC was seen in the 3 months following fingolimod discontinuation. In addition, there was no apparent association between patient nadir or mean ALC and the incidence of infection-related AEs. However, because patients with ALC falling below the threshold of $0.2 \times 10^{9} / \mathrm{L}$ discontinued study drug until ALC counts increased to $0.6 \times 10^{9} / \mathrm{L}$, the risk of infection for fingolimod-treated patients with ALC less than 0.2 $\times 10^{9} / \mathrm{L}$ cannot be adequately assessed using data from this study. In the PREFERMS study, ${ }^{20}$ the threshold for study drug discontinuation was lowered to $0.1 \times 10^{9} / \mathrm{L}$, and no new infectious complication signals were identified. While there is no specific recommendation in the US prescribing information to stop or modify fingolimod treatment based on predefined ALC levels, patients with ALC levels in the range $0.1-0.2 \times 10^{9} / \mathrm{L}$ had their treatment interrupted. ${ }^{1,21}$ In the US prescribing information, ALC ranges for reinitiation of fingolimod are also not specified. ${ }^{1}$ Instead, physicians in the US are advised to monitor patients for infections, as fingolimod may increase the risk of serious and life-threatening infections. By contrast, in Europe, interruption of fingolimod treatment is recommended when ALC counts are less than $0.2 \times 10^{9} / \mathrm{L}$, until recovery of lymphocyte levels. ${ }^{2}$

Compared with the participants in other fingolimod phase 3 trials, ${ }^{7,10,11}$ patients in the INFORMS study were, on average, approximately 10 years older and may therefore have been at a greater risk of infection. In the present study, the rate of any infection or infestation in the fingolimod group was similar to that in the placebo group (68.2\% vs $68.6 \%)$. Other studies in PPMS have also shown similar rates of infection between active treatments and placebo (where reported), including those evaluating immunosuppressant therapies, such as ocrelizumab (ORATORIO: ocrelizumab, 71.4\%; placebo, $69.9 \%)^{22}$ and rituximab (OLYMPUS: rituximab, 68.2\%; placebo, 65.3\%) ${ }^{23}$; as would be expected, those for glatiramer acetate were lower (PROMiSe: glatiramer acetate, $33.3 \%$; placebo, $39.2 \%$ ). ${ }^{24}$
Thus, the overall infection rates in INFORMS compare favorably with those reported in the other trials; however, any cross-study differences should be interpreted with caution.

The incidences of all infections, RTIs, and herpes infections were somewhat higher in patients who received fingolimod $1.25 \mathrm{mg} / \mathrm{d}$ than in those who received fingolimod $0.5 \mathrm{mg} / \mathrm{d}$ or placebo. This was expected, because similar results were reported in the phase 3, active-controlled trial of fingolimod in patients with relapsing-remitting MS. ${ }^{11}$ While the slight increase in infection rates with fingolimod $1.25 \mathrm{mg} / \mathrm{d}$ is not pertinent, because only the $0.5 \mathrm{mg} / \mathrm{d}$ dose is approved, ${ }^{1,2}$ it is interesting to note that the higher infection rate could not be correlated with lower ALC. This result suggests that, even at higher doses, there is no apparent link between infection rates and the magnitude of ALC reduction.

It should be noted that the INFORMS study recruited patients diagnosed with PPMS. While it may be assumed that findings from this MS subpopulation are also relevant to the general MS population, the infection rate results for patients with PPMS who received fingolimod $0.5 \mathrm{mg} / \mathrm{d}$ in the INFORMS study contrast somewhat with previous findings in patients with relapsing forms of MS. ${ }^{7,13,25,26}$ In the FREEDOMS study, lower RTIs (including bronchitis and pneumonia), but not upper RTIs or influenza infections, were more common in patients receiving fingolimod $0.5 \mathrm{mg} / \mathrm{d}$ than in those receiving placebo (lower RTIs: $9.6 \%$ vs $5.6 \%$, respectively). ${ }^{7}$ Moreover, herpes zoster infections were rare in clinical trials, ${ }^{25}$ but more common in patients receiving fingolimod $0.5 \mathrm{mg} / \mathrm{d}$ than in those receiving placebo ( $1.6 \%$ vs $1.0 \%$, respectively), ${ }^{25}$ which is consistent with rates of herpes zoster infections observed for fingolimod in the postmarketing setting ( 7 per 1,000 patientyears). ${ }^{26}$ Finally, it should be noted that although no rare but serious opportunistic infections such as cryptococcal meningitis, disseminated varicella, and progressive multifocal leukoencephalopathy were reported in the INFORMS study, 


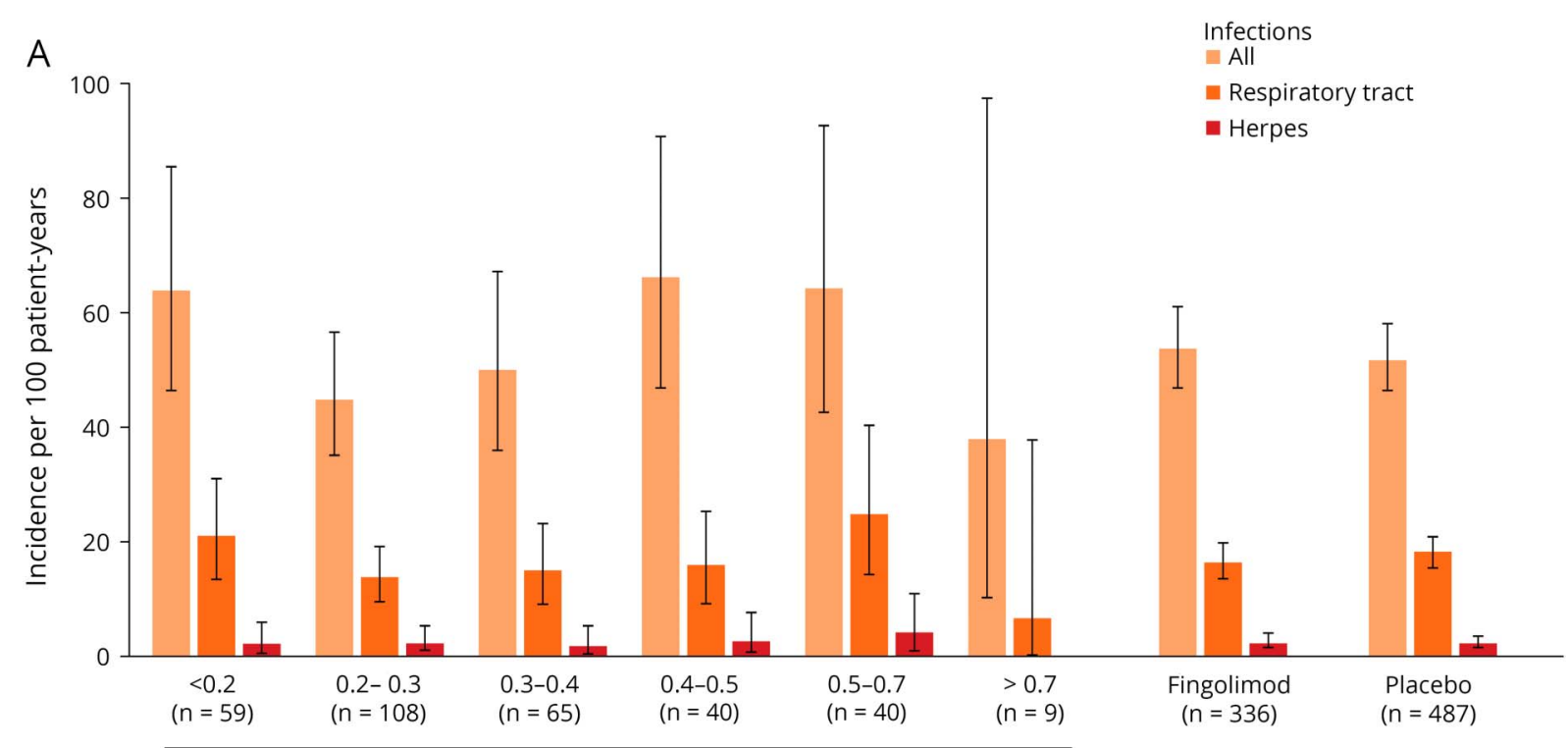

Nadir ALC $\times 10^{9} / \mathrm{L}$

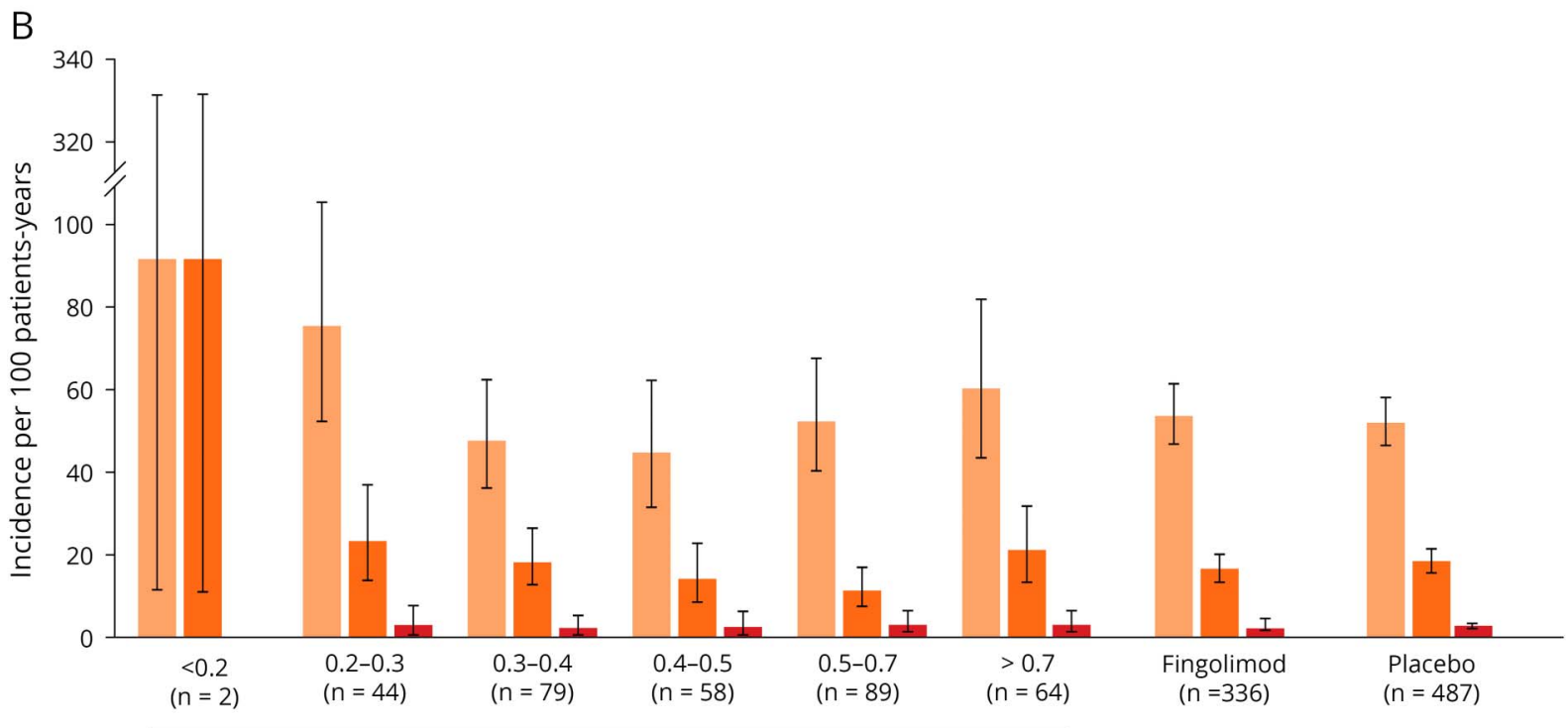

Mean ALC $\times 10^{\%} / L$

Incidences of all infections, RTIs, and herpes infections in patients receiving fingolimod $0.5 \mathrm{mg} / \mathrm{d}$ stratified by (A) nadir ALC and (B) mean ALC (left-hand side). The right-hand side shows the overall incidences in patients receiving fingolimod $0.5 \mathrm{mg} / \mathrm{d}$ or placebo. The $y$-axis scale break in (B) is to include the large intervals for ALC $<0.2 \times 10^{9} / \mathrm{L}$, owing to data being available for only 2 patients in this group. alncludes viral and other upper and/or lower RTIs. Includes oral $^{2}$ herpes, herpes simplex, herpes zoster, herpes zoster meningomyelitis, genital herpes, neurologic herpes, ophthalmic herpes simplex, and ophthalmic herpes zoster. Error bars represent $95 \% \mathrm{Cl}$. ALC = absolute lymphocyte count; RTI= respiratory tract infection.

cases have been reported in fingolimod-treated patients in the postmarketing setting. ${ }^{1}$

It is conceivable that factors other than low lymphocyte count could be associated with an increased risk of infection, such as low white blood cell count or low neutrophil count. However, significant leukopenia or neutropenia is rare with fingolimod. Indeed, the low number of patients with leukopenia or neutropenia in INFORMS precluded a definitive analysis, and suitably powered studies would be needed to determine whether there is a significantly increased risk of infection among these subjects. Further studies would be needed to investigate what factors, whether related to treatment, treatment history, or demographics of patients, could potentially be associated with an increased risk of infection in patients with MS.

In this analysis of safety data from the INFORMS study for up to 5 years, the incidence of infection-related AEs in patients with PPMS receiving fingolimod $0.5 \mathrm{mg} / \mathrm{d}$ was not greater than in those receiving placebo, and no new safety signals 
Table 2 Number and incidence of infections in the fingolimod $0.5 \mathrm{mg} / \mathrm{d}$ and placebo groups

\begin{tabular}{|c|c|c|c|c|c|}
\hline & \multicolumn{4}{|l|}{ Fingolimod $0.5 \mathrm{mg} / \mathrm{d}$} & \multirow[b]{2}{*}{$\begin{array}{l}\text { Placebo } \\
(n=487)\end{array}$} \\
\hline & $\begin{array}{l}\text { Nadir ALC }<0.2 \times 10^{9} / L \\
(n=59)\end{array}$ & $\begin{array}{l}\text { Nadir ALC } 0.2-0.4 \times 10^{9} / \mathrm{L} \\
(\mathrm{n}=179)\end{array}$ & $\begin{array}{l}\text { Nadir ALC }>0.4 \times 10^{9} / L \\
(n=98)\end{array}$ & $\begin{array}{l}\text { All patients } \\
(\mathrm{n}=336)\end{array}$ & \\
\hline $\begin{array}{l}\text { Any infection or } \\
\text { infestation }\end{array}$ & $45(63.9)$ & $117(46.3)$ & $67(64.5)$ & $229(53.6)$ & 334 (51.9) \\
\hline $\begin{array}{l}\text { Urinary tract } \\
\text { infection }\end{array}$ & $11(6.7)$ & $29(6.1)$ & $10(4.2)$ & $50(5.7)$ & $79(5.9)$ \\
\hline Upper RTI & $8(4.9)$ & $20(4.1)$ & $9(3.9)$ & $37(4.2)$ & $58(4.2)$ \\
\hline Influenza & $3(1.7)$ & $12(2.4)$ & $14(6.6)$ & $29(3.2)$ & $43(3.1)$ \\
\hline Bronchitis & $6(3.5)$ & $7(1.4)$ & $3(1.2)$ & $16(1.7)$ & $21(1.4)$ \\
\hline Gastroenteritis & $2(1.1)$ & $9(1.7)$ & $3(1.2)$ & $14(1.5)$ & $23(1.6)$ \\
\hline Sinusitis & $6(3.5)$ & $5(1.0)$ & $3(1.2)$ & $14(1.5)$ & $14(1.0)$ \\
\hline Oral herpes & $3(1.7)$ & $6(1.2)$ & $4(1.7)$ & $13(1.4)$ & $23(1.6)$ \\
\hline Herpes zoster & $1(0.5)$ & $5(1.0)$ & $4(1.6)$ & $10(1.1)$ & $9(0.6)$ \\
\hline Tooth infection & $0(0.0)$ & $8(1.6)$ & $2(0.8)$ & $10(1.1)$ & $5(0.3)$ \\
\hline Cystitis & $1(0.5)$ & $6(1.2)$ & $2(0.8)$ & $9(1.0)$ & $18(1.2)$ \\
\hline Rhinitis & $2(1.1)$ & $3(0.6)$ & $3(1.2)$ & $8(0.8)$ & $17(1.2)$ \\
\hline Onychomycosis & $1(0.5)$ & $4(0.8)$ & $2(0.8)$ & $7(0.7)$ & $11(0.7)$ \\
\hline Viral gastroenteritis & $0(0.0)$ & $4(0.8)$ & $3(1.2)$ & $7(0.7)$ & $9(0.6)$ \\
\hline RTI & $1(0.5)$ & $4(0.8)$ & $2(0.8)$ & $7(0.7)$ & $12(0.8)$ \\
\hline Folliculitis & $0(0.0)$ & $4(0.8)$ & $2(0.8)$ & $6(0.6)$ & $10(0.7)$ \\
\hline Nasopharyngitis & $1(0.5)$ & $3(0.6)$ & $1(0.4)$ & $5(0.5)$ & $11(0.7)$ \\
\hline Pharyngitis & $2(1.1)$ & $3(0.6)$ & $0(0.0)$ & $5(0.5)$ & $14(1.0)$ \\
\hline Lower RTI & $0(0.0)$ & $3(0.6)$ & $1(0.4)$ & $4(0.4)$ & $12(0.8)$ \\
\hline
\end{tabular}

Abbreviations: $\mathrm{AE}=$ adverse event; $\mathrm{ALC}=$ absolute lymphocyte count; $\mathrm{RTI}=$ respiratory tract infection.

Data are reported as numbers (incidences per 100 patient-y); values for infections and infestations are for those occurring in $\geq 2 \%$ of patients in the placebo group or any of the fingolimod $0.5 \mathrm{mg} / \mathrm{d}$ groups/subgroups in the period from the start of study drug or placebo administration, and up to $45 \mathrm{~d}$ after the last dose or up to February 28, 2017, whichever was the earlier.

AEs were coded using the Medical Dictionary for Regulatory Activities version 17.1 terminology.

related to reduced ALC were reported. There was no apparent relationship between nadir or mean ALCs and the incidence of all infections, RTIs, or herpes infections. These results suggest that the small increase in the risk of certain infections reported with fingolimod in the postmarketing setting may not be associated with low circulating lymphocyte counts. Further studies may help to elucidate the biological/immunologic mechanisms underlying this phenomenon.

\section{Acknowledgment}

The authors would like to thank all the patients who participated in the INFORMS study. The authors are also grateful to Dr. Norman Putzki (Novartis Pharmaceuticals Corporation, East Hanover, NJ) for his contributions to the development of these analyses. Medical writing support was provided by Oxford PharmaGenesis Ltd, Oxford, UK and was funded by Novartis.

\section{Study funding}

The INFORMS study and this analysis were funded by Novartis.

\section{Disclosure}

E.J. Fox has received personal compensation for consulting and/or research support from AbbVie, Biogen, Celgene, Chugai Pharma, EMD Serono, Roche Genentech, MedDay Pharma, Novartis, Sanofi Genzyme, Teva Pharmaceutical Industries, and TG Therapeutics. F.D. Lublin has received personal compensation for consulting from AbbVie, Acorda Therapeutics, Actelion, Apitope, Atara Biotherapeutics, Bayer HealthCare Pharmaceuticals, Biogen Idec, Brainstorm Cell Therapeutics, EMD Serono, Forward Pharma, Innate Immunotherapeutics, Mapi Pharma, MedDay Pharma, MedImmune, Novartis, Orion Biotechnology, Polpharma, Receptos/Celgene, Regeneron, Roche Genentech, Sanofi Genzyme, Teva Neuroscience, and TG Therapeutics, and 
research support from Actelion, NMSS, Novartis Pharmaceuticals Corporation, Sanofi, Teva Neuroscience, and Transparency Life Sciences. He has also received personal compensation as an editor for Multiple Sclerosis and Related Disorders. J.S. Wolinsky has received personal compensation for serving on scientific advisory or data monitoring committees, or other activities with AbbVie, Actelion, Alkermes, Bayer HealthCare, Biogen Idec, Bionest Partners, Celgene, Clene Nanomedicine, EMD Serono, Forward Pharma, GeNeuro, McDonnell Boehnen Hulbert \& Berghoff, MedDay Pharmaceuticals, Novartis, Otsuka, PTC Therapeutics, Roche Genentech, Sanofi Genzyme, and Takeda, and has received royalties for monoclonal antibodies out-licensed to Chemicon International through UTHealth. J.A. Cohen has received personal compensation for consulting for Alkermes, Biogen, Convelo, EMD Serono, ERT, Gossamer Bio, Novartis, and ProValuate; speaking for Mylan and Synthon; and serving as an Editor of Multiple Sclerosis Journal. I.M. Williams is an employee of Oxford PharmaGenesis. X. Meng, M. Ziehn, and S. Kolodny are employees of Novartis. B.A.C. Cree has received personal fees from AbbVie, Akili Interactive, Alexion, Biogen, EMD Serono, GeNeuro, Novartis, Sanofi Genzyme, and TG Therapeutics. Go to Neurology.org/NN for full disclosures.

\section{Publication history}

Received by Neurology: Neuroimmunology \& Neuroinflammation October 3, 2018. Accepted in final form July 1, 2019.

Appendix Authors

\begin{tabular}{|c|c|c|c|}
\hline Name & Location & Role & Contribution \\
\hline $\begin{array}{l}\text { Edward J. } \\
\text { Fox, MD, } \\
\text { PhD }\end{array}$ & $\begin{array}{l}\text { Central Texas } \\
\text { Neurology } \\
\text { Consultants, Round } \\
\text { Rock, TX }\end{array}$ & Author & $\begin{array}{l}\text { Design/conceptualization } \\
\text { of the study; acquisition, } \\
\text { analysis/interpretation of } \\
\text { data; drafting/revising } \\
\text { the manuscript for } \\
\text { intellectual content }\end{array}$ \\
\hline
\end{tabular}

Fred D. Ichan School of Author Design/conceptualization
Lublin، Medicine at Mount Author $\begin{aligned} & \text { Design/conceptualization } \\ & \text { of the study; acquisition, }\end{aligned}$ MD Sinai, New York, NY analysis/interpretation of data; drafting/revising the manuscript for intellectual content

\begin{tabular}{|c|c|c|c|}
\hline $\begin{array}{l}\text { Jerry S. } \\
\text { Wolinsky, } \\
\text { MD }\end{array}$ & $\begin{array}{l}\text { McGovern Medical } \\
\text { School, UTHealth, } \\
\text { Houston, TX }\end{array}$ & Author & $\begin{array}{l}\text { Design/conceptualization } \\
\text { of the study; acquisition, } \\
\text { analysis/interpretation of } \\
\text { data; drafting/revising } \\
\text { the manuscript for } \\
\text { intellectual content }\end{array}$ \\
\hline
\end{tabular}

\begin{tabular}{|c|c|c|c|}
\hline $\begin{array}{l}\text { Jeffrey A. } \\
\text { Cohen, } \\
\text { MD }\end{array}$ & $\begin{array}{l}\text { Mellen Center for } \\
\text { Multiple Sclerosis } \\
\text { Research, Cleveland, } \\
\mathrm{OH}\end{array}$ & Author & $\begin{array}{l}\text { Design/conceptualization } \\
\text { of the study; acquisition, } \\
\text { analysis/interpretation of } \\
\text { data; drafting/revising } \\
\text { the manuscript for } \\
\text { intellectual content }\end{array}$ \\
\hline
\end{tabular}

\begin{tabular}{|c|c|c|c|}
\hline $\begin{array}{l}\text { Ian M. } \\
\text { Williams, } \\
\text { PhD }\end{array}$ & $\begin{array}{l}\text { Oxford } \\
\text { PharmaGenesis, } \\
\text { Oxford, UK }\end{array}$ & Author & $\begin{array}{l}\text { Interpretation of the } \\
\text { data; drafting/revising } \\
\text { the manuscript for } \\
\text { intellectual content }\end{array}$ \\
\hline
\end{tabular}

Appendix (continued)

\begin{tabular}{|c|c|c|c|}
\hline Name & Location & Role & Contribution \\
\hline $\begin{array}{l}\text { Xiangyi } \\
\text { Meng, PhD }\end{array}$ & $\begin{array}{l}\text { Novartis } \\
\text { Pharmaceuticals } \\
\text { Corporation, East } \\
\text { Hanover, NJ }\end{array}$ & Author & $\begin{array}{l}\text { Design/conceptualization } \\
\text { of the study; analysis/ } \\
\text { interpretation of the data; } \\
\text { drafting/revising the } \\
\text { manuscript for } \\
\text { intellectual content }\end{array}$ \\
\hline
\end{tabular}

\begin{tabular}{|c|c|c|c|}
\hline $\begin{array}{l}\text { Marina } \\
\text { Ziehn, } \\
\text { PhD }\end{array}$ & $\begin{array}{l}\text { Novartis } \\
\text { Pharmaceuticals } \\
\text { Corporation, East } \\
\text { Hanover, NJ }\end{array}$ & Author & $\begin{array}{l}\text { Design/ } \\
\text { conceptualization of the } \\
\text { study; analysis/ } \\
\text { interpretation of the } \\
\text { data; drafting/revising } \\
\text { the manuscript for } \\
\text { intellectual content }\end{array}$ \\
\hline
\end{tabular}

\begin{tabular}{|c|c|c|c|}
\hline $\begin{array}{l}\text { Scott } \\
\text { Kolodny, } \\
\text { MD }\end{array}$ & $\begin{array}{l}\text { Novartis } \\
\text { Pharmaceuticals } \\
\text { Corporation, East } \\
\text { Hanover, NJ }\end{array}$ & Author & $\begin{array}{l}\text { Design/ } \\
\text { conceptualization of the } \\
\text { study; analysis/ } \\
\text { interpretation of the } \\
\text { data; drafting/revising } \\
\text { the manuscript for } \\
\text { intellectual content }\end{array}$ \\
\hline
\end{tabular}

\begin{tabular}{|c|c|c|c|}
\hline $\begin{array}{l}\text { Bruce A.C. } \\
\text { Cree, MD, } \\
\text { PhD, MAS }\end{array}$ & $\begin{array}{l}\text { UCSF Weill Institute } \\
\text { for Neurosciences, } \\
\text { San Francisco, CA }\end{array}$ & Author & $\begin{array}{l}\text { Design/ } \\
\text { conceptualization of the } \\
\text { study; acquisition, } \\
\text { analysis/interpretation } \\
\text { of data; drafting/ } \\
\text { revising the manuscript } \\
\text { for intellectual content }\end{array}$ \\
\hline
\end{tabular}

\section{References}

1. US Food and Drug Administration. Gilenya (fingolimod) prescribing information [online]. Available at: pharma.us.novartis.com/sites/www.pharma.us.novartis.com/ files/gilenya.pdf. Accessed July 18, 2018.

2. European Medicines Agency. Gilenya (fingolimod) summary of product charcteristics [online]. Available at: ema.europa.eu/docs/en_GB/document_library/EPAR_Product_Information/human/002202/WC500104528.pdf. Accessed July 18, 2018.

3. Winkelmann A, Loebermann M, Reisinger EC, Hartung HP, Zettl UK. Diseasemodifying therapies and infectious risks in multiple sclerosis. Nat Rev Neurol 2016; 12:217-233.

4. Subei AM, Cohen JA. Sphingosine 1-phosphate receptor modulators in multiple sclerosis. CNS Drugs 2015;29:565-575.

5. Comi G, Hartung HP, Bakshi R, Williams IM, Wiendl H. Benefit-risk profile of sphingosine-1-phosphate receptor modulators in relapsing and secondary progressive multiple sclerosis. Drugs 2017;77:1755-1768.

6. Mehling M, Johnson TA, Antel J, Kappos L, Bar-Or A. Clinical immunology of the sphingosine 1-phosphate receptor modulator fingolimod (FTY720) in multiple sclerosis. Neurology 2011;76:S20-S27.

7. Kappos L, Radue EW, O'Connor P, et al. A placebo-controlled trial of oral fingolimod in relapsing multiple sclerosis. N Engl J Med 2010;362:387-401.

8. Kaufmann M, Haase R, Proschmann U, Ziemssen T, Akgün K. Real world lab data: patterns of lymphocyte counts in fingolimod treated patients. Front Immunol 2018;9: 2669.

9. Fragoso YD, Spelman T, Boz C, et al. Lymphocyte count in peripheral blood is not associated with the level of clinical response to treatment with fingolimod. Mult Scler Relat Disord 2018;19:105-108.

10. Calabresi PA, Radue EW, Goodin D, et al. Safety and efficacy of fingolimod in patients with relapsing-remitting multiple sclerosis (FREEDOMS II): a double-blind, randomised, placebo-controlled, phase 3 trial. Lancet Neurol 2014;13:545-556.

11. Cohen JA, Barkhof F, Comi G, et al. Oral fingolimod or intramuscular interferon for relapsing multiple sclerosis. New Engl J Med 2010;362:402-415.

12. Khatri BO. Fingolimod in the treatment of relapsing-remitting multiple sclerosis: long-term experience and an update on the clinical evidence. Ther Adv Neurol Disord 2016;9:130-147.

13. Jeffery DR, Rammohan KW, Hawker K, Fox E. Fingolimod: a review of its mode of action in the context of its efficacy and safety profile in relapsing forms of multiple sclerosis. Expert Rev Neurother 2016;16:31-44.

14. Lublin F, Miller DH, Freedman MS, et al. Oral fingolimod in primary progressive multiple sclerosis (INFORMS): a phase 3, randomised, double-blind, placebocontrolled trial. Lancet (London, England) 2016;387:1075-1084.

15. World Medical Association. Declaration of Helsinki-Ethical principles for medical research involving human subjects. [online]. Available at: wma.net/policies-post/ wma-declaration-of-helsinki-ethical-principles-for-medical-research-involving-human-subjects/. Accessed July 18, 2018. 
16. Polman $\mathrm{CH}$, Reingold SC, Edan G, et al. Diagnostic criteria for multiple sclerosis: 2005 revisions to the "McDonald criteria". Ann Neurol 2005;58:840-846.

17. Sanai SA, Saini V, Benedict RH, et al. Aging and multiple sclerosis. Mult Scler 2016; 22:717-725.

18. Rabadi MH, Aston CE. Predictors of mortality in veterans with multiple sclerosis in an outpatient clinic setting. Int J MS Care 2017;19:265-273.

19. Wijnands JMA, Hoegg T, Zhu F, et al. Risk of infection-related hospitalizations in people with primary-progressive relative to relapsing-onset multiple sclerosis. Neurology 2016;86(16 suppl):353.

20. Cree BAC, Arnold DL, Cascione M, et al. Phase IV study of retention on fingolimod versus injectable multiple sclerosis therapies: a randomized clinical trial. Ther Adv Neurol Disord 2018;11:1756286418774338.

21. Fox EJ, Buckle GJ, Singer B, Singh V, Boster A. Lymphopenia and DMTs for relapsing forms of MS: considerations for the treating neurologist. Neurol Clin Pract 2019;9:53-63.
22. Montalban X, Hauser SL, Kappos L, et al. Ocrelizumab versus placebo in primary progressive multiple sclerosis. N Engl J Med 2017;376:209-220.

23. Hawker K, O'Connor P, Freedman MS, et al. Rituximab in patients with primary progressive multiple sclerosis: results of a randomized double-blind placebocontrolled multicenter trial. Ann Neurol 2009;66:460-471.

24. Wolinsky JS, Narayana PA, O'Connor P, et al. Glatiramer acetate in primary progressive multiple sclerosis: results of a multinational, multicenter, double-blind, placebo-controlled trial. Ann Neurol 2007;61:14-24.

25. Kappos L, Cohen J, Collins W, et al. Fingolimod in relapsing multiple sclerosis: an integrated analysis of safety findings. Mult Scler Relat Disord 2014;3:494-504.

26. Arvin AM, Wolinsky JS, Kappos L, et al. Varicella-zoster virus infections in patients treated with fingolimod: risk assessment and consensus recommendations for management. JAMA Neurol 2015;72:31-39. 


\section{Neurology \\ Neuroimmunology \& Neuroinflammation}

Lymphocyte counts and infection rates: Long-term fingolimod treatment in primary progressive MS

Edward J. Fox, Fred D. Lublin, Jerry S. Wolinsky, et al.

Neurol Neuroimmunol Neuroinflamm 2019;6;

DOI 10.1212/NXI.0000000000000614

This information is current as of September 11, 2019

Neurol Neuroimmunol Neuroinflamm is an official journal of the American Academy of Neurology.

Published since April 2014, it is an open-access, online-only, continuous publication journal. Copyright

Copyright $\odot 2019$ The Author(s). Published by Wolters Kluwer Health, Inc. on behalf of the American

Academy of Neurology.. All rights reserved. Online ISSN: 2332-7812.

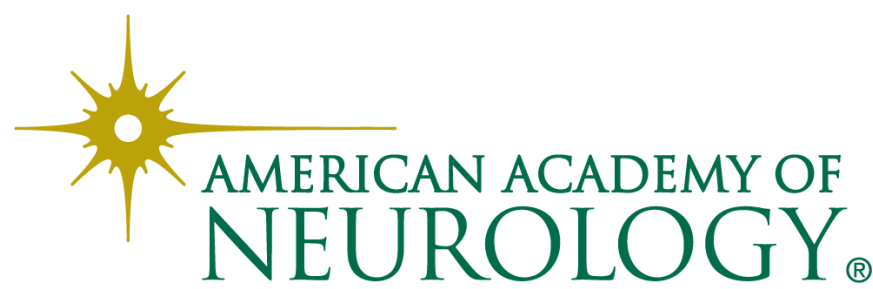




\section{Updated Information \& Services}

References

Citations

Subspecialty Collections

Permissions \& Licensing

Reprints including high resolution figures, can be found at: http://nn.neurology.org/content/6/6/e614.full.html

This article cites 23 articles, 1 of which you can access for free at: http://nn.neurology.org/content/6/6/e614.full.html\#\#ref-list-1

This article has been cited by 1 HighWire-hosted articles: http://nn.neurology.org/content/6/6/e614.full.html\#\#otherarticles

This article, along with others on similar topics, appears in the following collection(s):

\section{All Infections}

http://nn.neurology.org//cgi/collection/all_infections Clinical trials Randomized controlled (CONSORT agreement) $\mathrm{http} / / / \mathrm{nn}$.neurology.org//cgi/collection/clinical_trials_randomized_cont rolled_consort_agreement

Multiple sclerosis

http://nn.neurology.org//cgi/collection/multiple_sclerosis

Information about reproducing this article in parts (figures,tables) or in its entirety can be found online at:

http://nn.neurology.org/misc/about.xhtml\#permissions

Information about ordering reprints can be found online: http://nn.neurology.org/misc/addir.xhtml\#reprintsus

Neurol Neuroimmunol Neuroinflamm is an official journal of the American Academy of Neurology.

Published since April 2014, it is an open-access, online-only, continuous publication journal. Copyright

Copyright $\odot 2019$ The Author(s). Published by Wolters Kluwer Health, Inc. on behalf of the American Academy of Neurology.. All rights reserved. Online ISSN: 2332-7812.

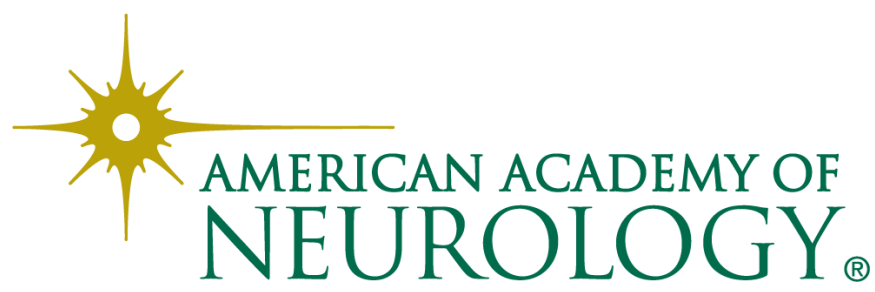

